\title{
Isolation and Characterization of Cellulase-producing Bacteria from Sugar Industry Waste
}

\author{
Farjana Islam ${ }^{1,2, *}$, Narayan Roy ${ }^{2}$ \\ ${ }^{1}$ Department of Biochemistry and Molecular Biology, Shahjalal University of Science and Technology, Sylhet, Bangladesh \\ ${ }^{2}$ Department of Biochemistry and Molecular Biology, University of Rajshahi, Rajshahi, Bangladesh
}

Email address:

farjanaislam308@gmail.com (F. Islam), nroy_64@yahoo.com (N. Roy)

${ }^{*}$ Corresponding author

\section{To cite this article:}

Farjana Islam, Narayan Roy. Isolation and Characterization of Cellulase-producing Bacteria from Sugar Industry Waste. American Journal of BioScience. Vol. 7, No. 1, 2019, pp. 16-24. doi: 10.11648/j.ajbio.20190701.13

Received: January 29, 2019; Accepted: March 8, 2019; Published: March 29, 2019

\begin{abstract}
Cellulases are inducible enzymes that are synthesized by a large number of microorganisms during their growth on cellulosic materials. This study focuses on the isolation and screening of cellulase-producing bacteria from sugar industry waste (molasses) and characterization by morphological and biochemical analysis. Further, purification of cellulase was carried by ammonium sulfate precipitation and followed by column chromatography and molecular weight determined by SDS-PAGE. The isolated bacterial strains were grown on carboxymethyl cellulose (CMC) agar plate at various optimum conditions like $\mathrm{pH}$, temperature, incubation period, carbon and nitrogen sources and substrate concentration. Three isolated strains showed clear hydrolyzing zone on agar plates containing CMC agar after Congo-red staining were identified as cellulase-producing bacteria. Based on cultural, morphological, and biochemical characteristics, the isolated strains were identified as Paenibacillus sp., Aeromonas sp., and Bacillus sp. Among the isolated strains, Paenibacillus $s p$. showed the capability for highest cellulase production $\left(0.89 \mu \mathrm{mol} \mathrm{ml} \mathrm{min}^{-1}\right)$ at optimal $\mathrm{pH} 7.0$ and $40^{\circ} \mathrm{C}$ temperature on 24 hour of the incubation period at $1 \% \mathrm{CMC}$ substrate concentration and was selected for further cellulase purification. In the final step of cellulase purification, the specific activity, purification fold and recovery were $1720 \mathrm{U} / \mathrm{mg}, 9.74$ and $35.6 \%$, respectively. The molecular weight of the purified enzyme was determined $66.9 \mathrm{kDa}$ and the enzyme showed a high specificity to CMC substrate. The bacterial strains present in molasses have the potential for cellulase production. Substrate specificity of the purified cellulase indicates it to be an endo- $\beta$ 1, 4-glucanase. The cellulase produced from the selected strain may benefit for industrial application.
\end{abstract}

Keywords: Cellulose, Cellulase, Molasses, Bacteria, Isolation, Optimization, Purification and Characterization

\section{Introduction}

Cellulose, a homopolymer of D-glucose units linked by $\beta-1$, 4 bonds, is the most abundant organic polymer on the earth [13]. It is an important structural component of the primary cell wall of green plants and potential renewable resources in the nature [4]. Therefore, it has raised an important economic interest to build up systems for effective management and use of cellulose-containing industrial wastes as inexpensive carbon sources [5]. Both bacteria and fungi have been known to produce a number of cellulases for biological degradation of cellulose [6]. Cellulases hydrolyze the cellulose into glucose molecule through the catalytic actions of 3 types of enzymes, namely endo- $\beta-1,4$ glucanase or carboxymethyl cellulase
(CMCase), $\beta$-D-glucosidase, and cellobiohydrolase [6, 7].

Cellulases have attracted much interest because of the diversity of their applications. Cellulases are used in the various industrial process, including textile and laundry, food, feed, leather, pulp and paper [4, 8-11]. In fiber modification, biomass fermentation and pharmaceutical sectors cellulases are also widely used [5, 12]. Application of cellulases in like these industries queries the highly stable cellulases that can work at increased $\mathrm{pH}$ and high temperature [9]. In recent years, researchers have been paying attention to various bacteria that produce cellulases because of their high growth rate and resistance to an extreme environment when compared to fungi and has a good potential in cellulase production. Bacteria belonging to the genera Clostridium, Cellulomonas, Bacillus, 
Ruminococcus, Bacteroides, Acetovibrio, Streptomyces, and Paenibacillus have been found to produce different types of cellulase when incubated under aerobic or anaerobic conditions [6]. Cellulases from various sources have distinctive features as they exhibit optimum $\mathrm{pH}$ and temperature, solubility depending on the amino acid composition [13]. Thermal stability and exact substrate specificity may also vary with their origin. Numerous microorganisms that are able to degrade cellulose have been isolated, screened and identified. However many studies have put more emphasis on cellulose degrading bacteria from agricultural, industrial and municipal wastes because the cellulases that they produced are easy to extract, and some of the bacterial cellulases have been used as commercial cellulase [14].

Although, a few number of bacteria can produce considerably large-scale bioactive compounds that are able to hydrolysis of crystalline cellulose in vitro. The key step of an industrial fermentation process development is the isolation of strains that are capable of producing the targeted products in commercial yields. This approach includes an extensive screening to test a big number of bacterial strains for identifying the potential cellulase producer with having some novel properties. Among several types of industrial wastes, the sugar industry wastes (molasses) are generally cellulosic in nature and the microorganisms available there have the capability to degrade large cellulose molecule into smaller monosaccharide units for their usual growth and development. Presence of some species of bacteria, yeast, and fungi in sugar industry wastes has been reported in a recent study [15]. This study aimed to isolate and screen the cellulase producing-bacteria from sugar industry wastes (molasses) and purify and characterize the cellulase produced by the isolated bacterial strains.

\section{Materials and Methods}

\subsection{Sample Collection, Isolation, and Screening for Cellulolytic Bacteria}

The samples (molasses) used in this study were collected from Rajshahi Sugar Mills located in Harian, Rajshahi, Bangladesh with discussing the authority maintaining the national guidelines. A serial dilution was made by taken $1 \mathrm{gm}$ of each sample. Then the sample (diluted up to $10^{-6}$ ) was taken into Luria-Bertani medium (LB). From each dilution $100 \mu \mathrm{l}$ of the solution was shifted into $1 \mathrm{~L}$ of carboxymethyl cellulose (CMC) agar plates containing $0.5 \mathrm{~g}$ of $\mathrm{KH}_{2} \mathrm{PO}_{4}, 0.25 \mathrm{~g} \mathrm{MgSO}_{4}$, $0.25 \mathrm{~g}$ cellulose and $2 \mathrm{~g}$ gelatin for increased the bacterial activity. Then the agar plates were incubated at $37^{\circ} \mathrm{C}$ for $24 \mathrm{~h}$ and stored at $4^{\circ} \mathrm{C}$ [16]. After incubation, the plates were submerged with $0.1 \%(\mathrm{w} / \mathrm{v})$ Congo-red solution for $15 \mathrm{~min}$ and discolored with $1 \mathrm{M} \mathrm{NaCl}$ solution. The degradation zone around the bacteria indicated that the strains could hydrolyze CMC. Enzyme activity of the isolated strains was confirmed by several types of assay like iodine solution, Congo-red, and filter-paper degradation assay [17-18]. Those bacteria that formed clear zones on CMC plates were subject to filter-paper degrading activity assay.

\subsection{Bacterial Identification by Morphological and Biochemical Characterization}

The isolated strains were identified based on morphological examination and biochemical characterizations.

\subsubsection{Morphological Characterization}

The agar plates were tested by microscopic viewing and Gram staining technique for the identification of isolated strains [19]. Gram staining technique was applied to differentiate between gram-positive and gram-negative bacteria. The isolated strains were divided into two groups based on whether they retain or lose crystal violet color after iodine and alcohol treatment and counterstaining with safranin.

\subsubsection{Biochemical Characterization}

The parameters investigated for biochemical characterizations were Carbohydrate fermentation test, Catalase test, Motility test, Congo-red test, Methyl-red test, $\mathrm{H}_{2} \mathrm{~S}$ production, Citrate utilization test, and Voges-Proskauer test by standard protocols [20].

\subsection{Optimization of Different Culture Parameters for Cellulase Production}

Different culture conditions such as $\mathrm{pH}$, temperature, incubation time, substrate concentration, and carbon sources were optimized for the isolated bacterial strains. The selected strains were placed in CMC media and tested at different parameters. The influence of the parameters on cellulase production was estimated by measuring the enzyme activity at several $\mathrm{pH}$ levels ranging from 5 to 11 and temperature varying from $20^{\circ} \mathrm{C}$ to $45^{\circ} \mathrm{C}$ and incubation period ranging from 24 to $96 \mathrm{~h}$ at $37^{\circ} \mathrm{C}$. The CMC substrate concentrations from 0.5 to $2 \%$ were used for getting the highest enzyme production. Carbon and nitrogen sources were replaced by several substances. Carbon sources included xylose, birchwood xylan, starch, carboxymethyl cellulose, oat spelt xylan, lactose, rich bran xylan, cellobiose, wheat bran, chitin and xylan. Applied nitrogen sources were yeast extract, peptone, tryptone, urea, casein, asparagines, ammonium, phosphate, potassium nitrate and sodium nitrite. Different type of metal salts like $\mathrm{NaCl}, \mathrm{KCl}, \mathrm{CaCl}_{2}, \mathrm{MnCl}_{2}$ and $\mathrm{MgCl}_{2}$ were used to look their effects on bacterial growth and cellulase production. All factors effects on enzyme production were estimated by measuring cellulase activity.

\subsection{Enzyme Activity Assay}

\subsubsection{Preparation of Crude Enzyme}

For secondary screening and cellulase production, the bacterial isolates were incubated overnight at $37^{\circ} \mathrm{C}$ that exhibited a maximum zone of hydrolysis was cultured in Luria-Bertani medium. The cultures were then centrifuged for $15 \mathrm{~min}$ at $8000 \mathrm{rpm}$ and the clear supernatant was used as a source of crude enzyme solution. The crude enzyme solution $(1500 \mathrm{ml})$ was stored and applied for enzyme purification and measurement of enzyme activity. 


\subsubsection{DNS Method}

Cellulase activity was determined by 3,5-dinitrosalicylic acid (DNS) method through measuring of the amount of reducing sugars released from CMC dissolved in $1 \mathrm{~N}$ citrate buffer, $\mathrm{pH} 5.0$ [21]. Briefly, $100 \mu \mathrm{l}$ of crude enzyme and $1 \mathrm{ml}$ of citrate buffer were added into $1 \mathrm{ml}$ of $\mathrm{CMC}$ substrate solution. Then the reaction mixture was incubated at $45^{\circ} \mathrm{C}$ for $30 \mathrm{~min}$. DNS reagent was added to stop the reaction [21]. The treated samples were boiled for $10 \mathrm{~min}$ and cooled in water to stabilize the color. The optical density (OD) was determined at $540 \mathrm{~nm}$. Cellulase activity was measured based on glucose standard calibration curve. One unit of enzyme activity was defined as the amount of enzyme that liberated $1 \mu \mathrm{mol}$ of glucose per min [5].

\subsubsection{Filter-paper Activity Assay}

Those bacterial isolates showing cellulase activity on CMC plates were further screened for quality of cellulase activity by transferring $100 \mu \mathrm{l}$ of overnight culture to $5 \mathrm{~mL}$ of basal salts media $\left(\mathrm{NaNO}_{3} 2.5 \mathrm{~g} ; \mathrm{KH}_{2} \mathrm{PO}_{4} 2 \mathrm{~g} ; \mathrm{MgSO}_{4} 0.2 \mathrm{~g} ; \mathrm{NaCl} 0.2 \mathrm{~g}\right.$; $\mathrm{CaCl}_{2} \cdot 6 \mathrm{H}_{2} \mathrm{O} 0.1 \mathrm{~g}$ in a liter) with a $70 \mathrm{~cm}$ wide strip of filter paper (Whatman filter paper no.1) and two drops of $10 \mathrm{nM}$ glucose in glass culture tubes. The cultures were incubated for 7 days and viewed daily for visual evidence of filter paper degradation. Those strains capable of completely degrading the filter paper were selected for further quantitative analysis. This test was done in both aerobic and oxygen-limited conditions by sealing the tubes with parafilm. Filter-paper cellulase (FPase) activity was determined by DNS method. The reaction system was prepared as follows: $500 \mu \mathrm{L}$ enzymes mixed with $50 \mathrm{mg}$ of filter paper $(1.0 \times 6.0)$ in $1 \mathrm{~mL}$ buffer for determining the FPase activity. Sodium citrate buffer $(100 \mathrm{mM})$ was used for dissolving or re-suspending the substrate. The mixture was incubated for $1 \mathrm{~h}$. The reaction was then stopped by adding 3 $\mathrm{mL}$ of DNS reagent. The mixture was heated in boiling water for $5 \mathrm{~min}$ for color development. Then the absorbance was determined at $540 \mathrm{~nm}$.

\subsection{Purification of Cellulase}

\subsubsection{Ammonium Sulfate Precipitation}

$1500 \mathrm{ml}$ of crude enzyme was lead to $80 \%$ saturation with ammonium sulfate. The mixture was kept at $4{ }^{\circ} \mathrm{C}$ in a magnetic stirrer for overnight. For further purification, the mixture was then centrifuged and the pellet was dissolved in $50 \mathrm{mM}$ of sodium phosphate buffer saline maintaining $\mathrm{pH}$ 7.0. Dialysis of partially purified enzyme was done against the phosphate buffer.

\subsubsection{DEAE-cellulose Column Chromatography}

$60 \mathrm{ml}$ of enzyme solution was loaded to the Diethylaminoethyl cellulose (DEAE-cellulose) column which was equilibrated with Tris- $\mathrm{HCl}$ buffer $(10 \mathrm{mM})$ at $\mathrm{pH} 7.0$. The unbound fraction was used for determining cellulase activity at $540 \mathrm{~nm}$ and measuring protein concentration at $280 \mathrm{~nm}$. The eluted fraction exhibiting maximum activity was pooled and stored for sodium dodecyl sulfatepolyacrylamide gel electrophoresis (SDS-PAGE).

\subsubsection{CM-cellulose Column Chromatography}

The unbound solution $(55 \mathrm{ml})$ from DEAE was loaded to the CM-cellulose column and equilibrated with $10 \mathrm{mM}$ Tris$\mathrm{HCl}$ buffer at $\mathrm{pH}$ 7.0. Then proteins were eluted gradually by increasing the $\mathrm{NaCl}$ gradient $(0.0$ to $0.3 \mathrm{M})$ with using same buffer solution. The eluted fractions having cellulase activity $(25 \mathrm{ml})$ were collected and kept for enzyme activity assay and electrophoresis.

\subsection{Protein Concentration and Molecular Weight Determination}

Protein concentrations in crude solution were measured by Lowry's Method with bovine serum albumin (BSA) as a reference marker [22]. The molecular mass of the purified cellulase was measured using SDS-PAGE [23]. In SDSPAGE, standard proteins marker was applied next to the purified protein, followed by the dialyzed and crude sample.

\subsection{Substrate Specificity Determination}

The hydrolytic ability of purified cellulase (from Paenibacillus sp.) against CMC, cellulose, xylose, lactose, oat spelt xylan, rich bran xylan, and wheat bran xylan was measured for assessing the specificity to substrates [16].

\section{Results}

\subsection{Isolation, Screening and Identification of Cellulase-Producing Bacteria}

Three bacterial strains marked as $\mathrm{C}_{1}, \mathrm{C}_{2}$ and $\mathrm{C}_{3}$ were isolated from molasses and cultured in $\mathrm{CMC}$ agar media. These strains showed hydrolyzing zones on agar plates after Congo-red staining (Figure 1).

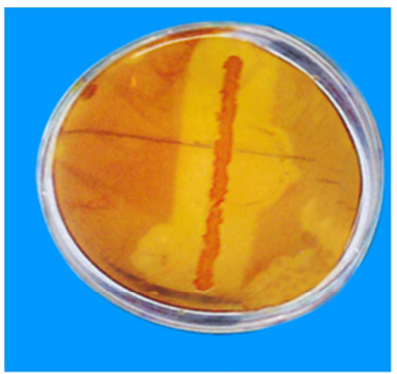

$\mathrm{C}_{1}$

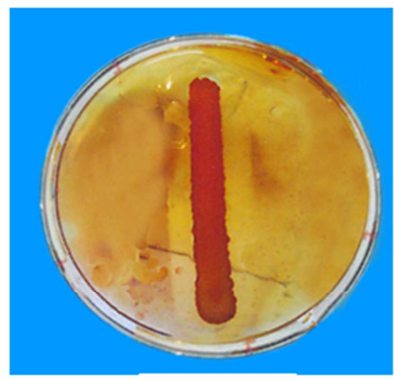

$\mathrm{C}_{2}$

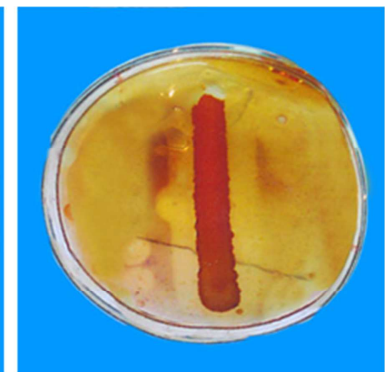

$\mathrm{C}_{3}$

Figure 1. Congo red test for confirmation of Cellulolytic activity by the isolated bacterial strains: $C_{1}$ (Paenibacillus sp.), $C_{2}$ (Bacillus sp.) and $C_{3}$ (Aeromonas sp.). 
A microscopic observation indicated that the $\mathrm{C}_{1}$ and $\mathrm{C}_{2}$ strain were rod-shaped and $\mathrm{C}_{3}$ strain was short rod-shaped bacteria (Figure 2). In Gram staining technique, the two isolates $\mathrm{C}_{1}$ and $\mathrm{C}_{2}$ showed a minimum zone of clearance and were found to be gram-positive and $\mathrm{C}_{3}$ showed the maximum zone of clearance and was found to be gram-negative bacteria. Physiological and biochemical characteristics for the bacterial isolates are presented in Table 1 .

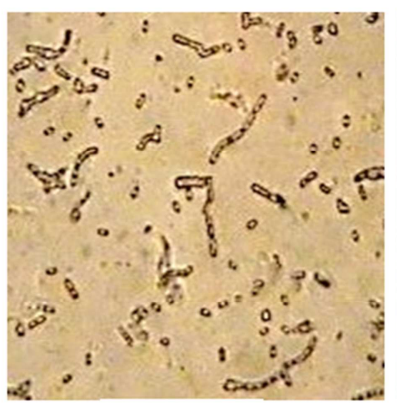

$\mathrm{C}_{1}$ strain

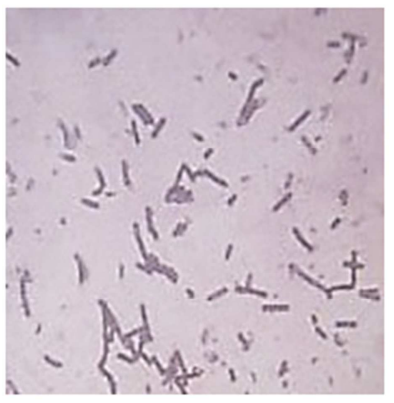

$\mathrm{C}_{2}$ strain

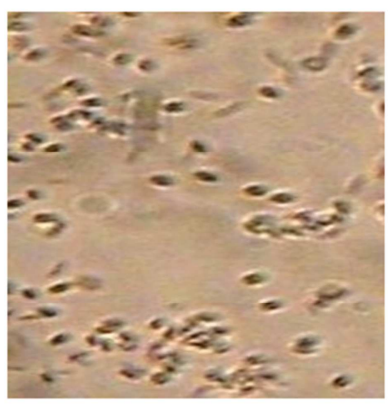

$C_{3}$ strain

Figure 2. Microscopic view of gram-positive $\left(C_{1}\right.$, Paenibacillus sp. and $C_{2}$, Bacillus sp.) and gram-negative ( $C_{3}$, Aeromonas sp.) rods.

Table 1. Physiological and biochemical characteristics of the bacterial isolates.

\begin{tabular}{llll}
\hline & $\mathbf{C}_{\mathbf{1}}$ strain & $\mathbf{C}_{\mathbf{2}}$ strain & $\mathbf{C}_{\mathbf{3}}$ strain \\
\hline Morphology & Rod & Rod & Short rod \\
Gram Staining & + & + & - \\
Motility test & + & + & + \\
Glucose Fermentation & + & + & + \\
Galactose Fermentation & + & + & + \\
Sucrose Fermentation & + & + & + \\
Catalase test & + & + & + \\
Citrate Utilization & - & + & + \\
Methyl-Red test & + & - & + \\
Voges-Proskauer test & - & + & - \\
$\mathrm{H}_{2}$ S Production test & - & - & - \\
\hline
\end{tabular}

According to morphological and biochemical tests, the selected strains were identified to be Paenibacillus sp. $\left(\mathrm{C}_{1}\right)$, Bacillus sp. $\left(\mathrm{C}_{2}\right)$, and Aeromonas sp. $\left(\mathrm{C}_{3}\right)$, respectively. In filterpaper degradation test, these strains were observed to complete degrade the filter-paper which indicates the cellulolytic properties of the isolated bacterial strains (Figure 3).

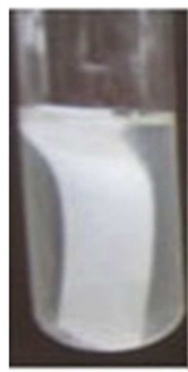

Control

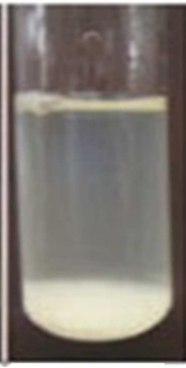

$C_{1}$ strain

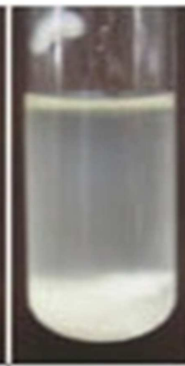

$C_{2}$ strain

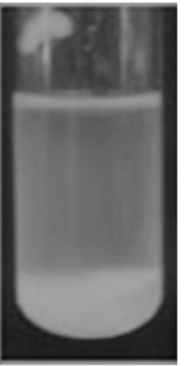

$C_{3}$ strain
Figure 3. Qualitative test for filter paper degradation by the isolated bacterial strains: $C_{1}$ (Paenibacillus sp.), $C_{2}$ (Bacillus sp.) and $C_{3}$ (Aeromonas sp.).

\subsection{Optimization of Culture Conditions and Enzyme Production}

The optimized culture conditions and cellulase production for the isolated strains are presented in Table 2. The bacterial growth for strain $\mathrm{C}_{1}$ (Paenibacillus $s p$.) was better in neutral $\mathrm{pH} 7.0$ and exhibited maximum enzyme activity $\left(0.89 \mu \mathrm{mol} \mathrm{ml} \mathrm{min}^{-1}\right)$, while $\mathrm{C}_{2}$ and $\mathrm{C}_{3}$ strains showed moderate enzyme activity $\left(0.70\right.$ and $0.38 \mu \mathrm{mol} \mathrm{ml}{ }^{-1}$ $\min ^{-1}$ ) at $\mathrm{pH} 6.0$ and $\mathrm{pH} 7.0$, respectively. The optimum temperature for the growth of all strains was found to be $40^{\circ} \mathrm{C}$. Cellulase production by $\mathrm{C}_{1}$ strain was gradually increased and showed the maximum enzyme activity $(0.98$ $\mu \mathrm{mol} \mathrm{ml}{ }^{-1} \mathrm{~min}^{-1}$ ) on $24 \mathrm{~h}$ of the incubation period and other two strains $\left(\mathrm{C}_{2}\right.$ and $\left.\mathrm{C}_{3}\right)$ showed moderate enzyme activity $\left(0.77\right.$ and $\left.0.67 \mu \mathrm{mol} \mathrm{ml} \mathrm{min}^{-1} \mathrm{~min}^{-1}\right)$ on $36 \mathrm{~h}$ of the incubation time and gradually declined afterward. The $\mathrm{C}_{1}$ isolate produced the large amount of cellulase and exhibited the highest activity $\left(0.97 \mu \mathrm{mol} \mathrm{ml} \mathrm{min}^{-1}\right)$ at $1 \%$ of $\mathrm{CMC}$, whereas, $\mathrm{C}_{2}$ and $\mathrm{C}_{3}$ isolates showed maximum activity $(0.72$ $\mu \mathrm{mol} \mathrm{ml} \mathrm{min}^{-1}$ and $0.35 \mu \mathrm{mol} \mathrm{ml}^{-1} \mathrm{~min}^{-1}$ ) at $1.5 \%$ and $2 \%$ of $\mathrm{CMC}$ substrate concentration, respectively. Among various types of carbon sources, CMC was the prominent source for the bacterial growth and enzyme production. As a nitrogen source, peptone was the most suitable one for bacterial growth and better cellulase production and among different types of metal salts, $\mathrm{CaCl}_{2}$ showed the profound effect on cellulase production for the strain $\mathrm{C}_{1}$ (data not shown). The optimum temperature and $\mathrm{pH}$ of the purified cellulase from $\mathrm{C}_{1}$ strain was same $\left(40^{\circ} \mathrm{C}\right.$ and $\left.\mathrm{pH} 7.0\right)$ as observed early culture conditions.

Table 2. Optimaization of culture conditions for the isolated bacterial strains.

\begin{tabular}{|c|c|c|c|c|}
\hline \multirow{2}{*}{ Different parameters } & \multirow{2}{*}{ Different values } & \multicolumn{3}{|c|}{ Enzyme Activity $\left(\mu \mathrm{mol} \mathrm{ml} \mathrm{l}^{-1} \mathrm{~min}^{-1}\right)$} \\
\hline & & $\mathrm{C}_{1}$ & $\mathrm{C}_{2}$ & $\mathrm{C}_{3}$ \\
\hline \multirow[t]{2}{*}{$\mathrm{pH}$} & 5 & 0.55 & 0.47 & 0.20 \\
\hline & 6 & 0.75 & 0.70 & 0.25 \\
\hline
\end{tabular}




\begin{tabular}{|c|c|c|c|c|}
\hline \multirow{2}{*}{ Different parameters } & \multirow{2}{*}{ Different values } & \multicolumn{3}{|c|}{ Enzyme Activity $\left(\mu \mathrm{mol} \mathrm{ml}{ }^{-1} \min ^{-1}\right)$} \\
\hline & & $\mathrm{C}_{1}$ & $\mathbf{C}_{2}$ & $\mathbf{C}_{3}$ \\
\hline \multirow{11}{*}{ Temperature $\left({ }^{\circ} \mathrm{C}\right)$} & 7 & 0.89 & 0.60 & 0.38 \\
\hline & 8 & 0.70 & 0.55 & 0.30 \\
\hline & 9 & 0.55 & 0.35 & 0.22 \\
\hline & 10 & 0.21 & 0.12 & 0.09 \\
\hline & 11 & 0.11 & 0.09 & 0.07 \\
\hline & 20 & 0.25 & 0.20 & 0.09 \\
\hline & 25 & 0.45 & 0.30 & 0.15 \\
\hline & 30 & 0.70 & 0.50 & 0.19 \\
\hline & 35 & 0.80 & 0.60 & 0.29 \\
\hline & 40 & 0.93 & 0.70 & 0.39 \\
\hline & 45 & 0.40 & 0.24 & 0.15 \\
\hline \multirow[t]{7}{*}{ Incubation period $(\mathrm{h})$} & 12 & 0.67 & 0.57 & 0.23 \\
\hline & 24 & 0.98 & 0.60 & 0.57 \\
\hline & 36 & 0.88 & 0.77 & 0.67 \\
\hline & 48 & 0.55 & 0.33 & 0.22 \\
\hline & 60 & 0.17 & 0.09 & 0.07 \\
\hline & 72 & 0.09 & 0.05 & 0.04 \\
\hline & 96 & 0.07 & 0.03 & 0.02 \\
\hline \multirow[t]{4}{*}{ Substrate concentration (\%) } & 0.5 & 0.60 & 0.45 & 0.10 \\
\hline & 1.0 & 0.97 & 0.60 & 0.19 \\
\hline & 1.5 & 0.50 & 0.72 & 0.25 \\
\hline & 2.0 & 0.30 & 0.20 & 0.35 \\
\hline \multirow[t]{10}{*}{ Carbon sources } & Xylose & 0.40 & 0.40 & 0.05 \\
\hline & Birch wood xylan & 0.42 & 0.35 & 0.12 \\
\hline & Oat spelt xylan & 0.41 & 0.44 & 0.14 \\
\hline & Rice bran xylan & 0.42 & 0.37 & 0.19 \\
\hline & Starch & 0.35 & 0.32 & 0.19 \\
\hline & Carboxymethyl cellulose & 0.85 & 0.67 & 0.29 \\
\hline & Cellobiose & 0.80 & 0.55 & 0.25 \\
\hline & Lactose & 0.12 & 0.09 & 0.08 \\
\hline & Wheat bran xylan & 0.38 & 0.21 & 0.18 \\
\hline & Chitin & 0.05 & 0.04 & 0.03 \\
\hline
\end{tabular}

\subsection{Cellulase Purification}

Summary for the purification of cellulase is shown in Table 3. The unrefined enzyme extract consists $301 \mathrm{mg}$ of protein exhibited $81790 \mathrm{U}$ in terms of entire activity.

Table 3. Summary of the purification of cellulase from crude sample of Paenibacillus sp.

\begin{tabular}{llllll}
\hline Procedure & $\begin{array}{l}\text { Total protein } \\
(\mathbf{m g})\end{array}$ & Total activity (U) & $\begin{array}{l}\text { Specific activity } \\
\text { (U/mg) }\end{array}$ & $\begin{array}{l}\text { Purification } \\
\text { (Fold) }\end{array}$ & Recovery (\%) \\
\hline Enzyme crude extract & 301 & 81790 & 272 & 1.00 & 99.9 \\
Ammonium sulfate saturation (80\%) & 160 & 75125 & 470 & 1.72 & 91.9 \\
DEAE-cellulose column chromatography & 40 & 64530 & 1613 & 5.91 & 78.8 \\
CM-cellulose column chromatography & 17 & 29250 & 1720 & 9.74 & 35.6 \\
\hline
\end{tabular}

Due to the forwarding steps of purification, the amount of total activity and total protein were going to be decreased and the specific activity and purification fold was increased gradually. In the first stage of cellulose purification, the specific activity and purification fold were $272 \mathrm{U} / \mathrm{mg}$ and 1.0 , respectively. In the final step of purification with CMcellulose column chromatography, the specific activity, purification fold and recovery were $1720 \mathrm{U} / \mathrm{mg}, 9.74$ and
$35.6 \%$, respectively.

\subsection{Molecular Weight Determination}

According to the SDS-PAGE profile, molecular weight of the purified cellulase was found to be $66.9 \mathrm{kDa}$ comparing with the marker proteins (Figure 4). 


\section{$\begin{array}{llll}4 & 3 & 2 & 1\end{array}$}

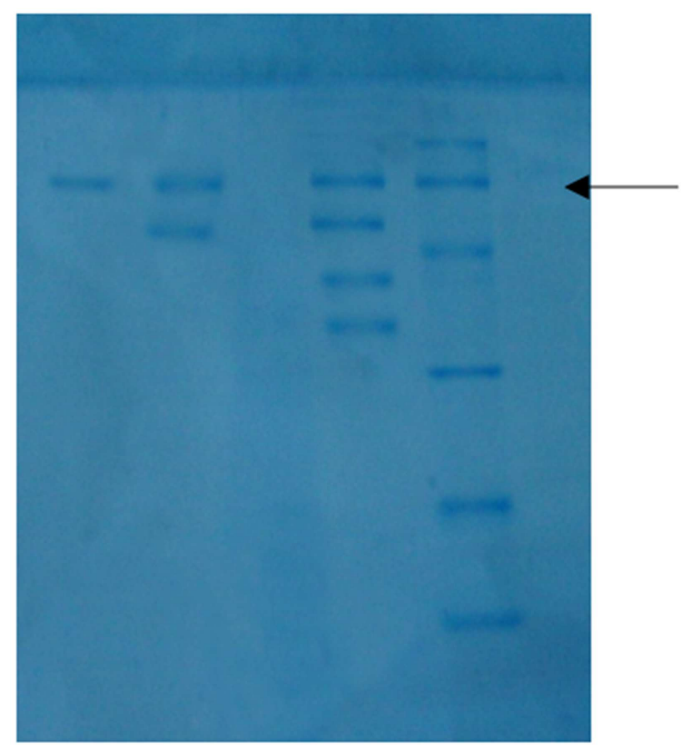

\section{$66.9 \mathrm{kDa}$}

Figure 4. Determination of molecular weight by SDS-PAGE analysis. Lane 1, marker proteins: [top to bottom: Phosphorylase B (97 kDa), Bovine serum albumin (67 kDa), Ovalbumin (45 kDa), Carbonic anhydrase (29 kDa), Trypsin inhibitor (20 kDa) and Lysozyme (14.6 kDa)]. Lane 2, crude enzyme. Lane 3, DEAE-cellulose unbound fraction and Lane 4, CM-cellulose bound (purified protein). The migration position of cellulase is indicated as 66.9 $\mathrm{kDa}$.

\subsection{Substrate Specificity}

The cellulase purified from strain $\mathrm{C}_{1}$ exhibited the highest activity against CMC substrate. There was moderate hydrolytic activity against, lactose wheat bran xylan, rice xylan, and low activity to xylose and oat spelt xylan (Figure
5). The purified enzyme was found to be stable at $\mathrm{pH} 7.0$ and $40^{\circ} \mathrm{C}$ temperature against $\mathrm{CMC}$ and at this stage, the enzyme didn't lose any activity (Figure 5). Based on substrate specificity, the purified cellulase showed maximum activity on $\mathrm{CMC}$ which indicated it to be an endo- $\beta$-1, 4-glucanase.
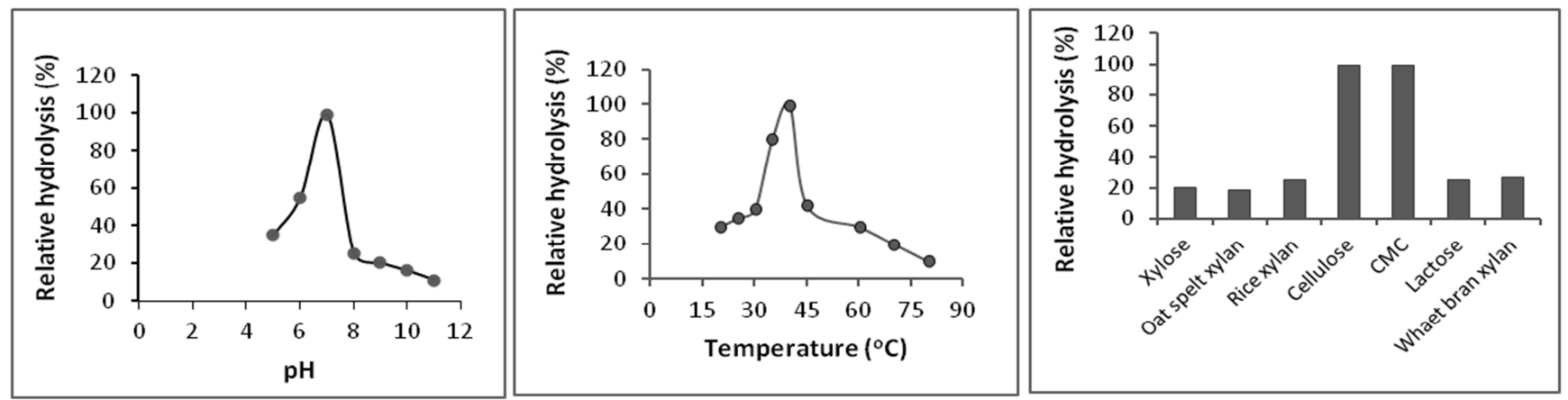

Figure 5. Characterization of purified cellulase from Paenibacillus sp.: (A) Effect of $p H$, (B) Effect of temperature and (C) Effect of different substrates on cellulase activity.

\section{Discussion}

The biological degradation of cellulose has been investigated for many years. A number of cellulolytic enzymes, especially cellulases from different bacterial strains have been purified and characterized. The cellulolytic activities of the isolated strains depend on the sources and volume of biowaste in nature [24]. In this study, sugar industry waste (molasses) was selected as a source for obtaining desirable cellulase-producing bacteria. The isolated strains $\left(\mathrm{C}_{1}, \mathrm{C}_{2}\right.$ and $\left.\mathrm{C}_{3}\right)$ were cellulolytic bacteria confirmed by filter-paper degradation, Gram's iodine and Congo-red staining assay and cellulase activity of each strain was confirmed and determined by measuring the amount of reducing sugar liberated from cellulose by DNS method [21, 25].

Based on morphological, cultural and biochemical characteristics, the bacterial strains were identified as Paenibacillus sp. $\left(\mathrm{C}_{1}\right)$, Bacillus sp. $\left(\mathrm{C}_{2}\right)$ and Aeromonas sp. $\left(\mathrm{C}_{3}\right)$, where the strains $\mathrm{C}_{1}$ and $\mathrm{C}_{2}$ were gram-positive and $\mathrm{C}_{3}$ was gram-negative. The strains inoculation was performed in the fermentation medium and enzyme production was measured $[19,26]$. Cellulase production by the specific strains was tested at various cultural conditions, like $\mathrm{pH}$, temperature, substrate concentration, incubation period, carbon, and nitrogen sources [27-28).

In this study, Paenibacillus sp. showed highest cellulase activity at optimal $\mathrm{pH} 7.0$ and temperature at $40^{\circ} \mathrm{C}$ on 24 
hours incubation period at $1 \% \mathrm{CMC}$ concentration. The other two strains Bacillus sp. and Aeromonas sp. exhibited comparatively less cellulase activity than Paenibacillus $s p$. at $\mathrm{pH} 6.0$ and 7.0 at $40^{\circ} \mathrm{C}$ temperature on $36 \mathrm{~h}$ incubation period at $1.5 \%$ and $2 \% \mathrm{CMC}$ concentration, respectively. In a previous study, the isolated strain Bacillus subtilis from the agricultural fields exhibited highest cellulase activity at culture condition between $\mathrm{pH} 6.5$, and 7.5 at $45^{\circ} \mathrm{C}$ temperature at $1.5 \% \mathrm{CMC}$ agar medium [29]. In a recent study, Bacillus sp. SM3-M8 was isolated from waste (molasses) and characterized by morphological and biochemical tests and the isolate was found to show highest cellulase activity at $\mathrm{pH} 7.0$, temperature $45^{\circ} \mathrm{C}$ and $\mathrm{CMC}$ concentration at $0.5 \%$ after $48 \mathrm{~h}$ of incubation period [15]. A similar finding was found in a previous study where the cellulase purified from Paenibacillus $s p$. E2 and E4 in paper mill sludges exhibited maximum enzymatic activity on filterpaper and CMC substrate [30].

Paenibacillus genus is acquainted to contain some better cellulase making strains, E2 and E4 showed high cellulase activities and represent excellent candidates for further cellulase analysis and characterization reported in the study investigated by Maki et al. [30]. To characterize the specificity of the purified enzyme, we initially applied filter paper degradation assay and CMC test. CMC agar helps us to identify the bacterial isolates having cellulase activity on soluble cellulose like CMC thus indicating commonly endoglucanase activities. Then, the isolates showing cellulase activity were screened on CMC substrate for activity on filter paper. In substrate specificity assay, the purified cellulase exhibit maximum activity to $\mathrm{CMC}$ and less activity to xylose, wheat bran xylan and rice xylan. This specificity on CMC indicates that the CMCase purified from Paenibacillus sp. may be an endoglucanase according to the definition by Coughlan and Mayer [31].

The term CMCase has commonly been regarded as synonymous with endoglucanase which randomly degrades CMC or amorphous cellulose and has no activity or low activity on other substrates [31]. Therefore, in our study, the substrate specificity test indicates that cellulase purified from the selected strain may be an endo- $\beta-1,4$-glucanase. In a related study, researchers have also isolated and characterized a novel endoglucanase (Ce19P) according to CMC substrate specificity from a recently isolated Paenibacillus sp. BME14 [32]. The Endoglucanase Cel9P showed 65\% of highest activity at $5^{\circ} \mathrm{C}$, which can be useful for industries that have processed at lower temperatures [32]. In another study, a thermophilic, cellulose-degrading bacterium Paenibacillus $s p$. strain B39 was isolated from the poultry manure compost exhibited high activity on CMC was indicated as endoglucanase based on CMC substrate activity [33].

Taking into account the maximum cellulase activity, the strain Paenibacillus sp. was chosen for enzyme purification, enzyme characterization and molecular weight determination [34]. In the first step of enzyme purification, the specific activity and purification fold were $272 \mathrm{U} / \mathrm{mg}$ and 1.0, respectively and in the last step of purification, the specific activity, purification fold and recovery were $1720 \mathrm{U} / \mathrm{mg}, 9.74$ and $35.6 \%$, respectively. The molecular weight of the purified enzyme was found to be $66.9 \mathrm{KDa}$ and the enzyme was characterized at optimized conditions against several substrates. In various substrates, CMC was found as an important source for highest CMCase (endoglucanase) production and the purified cellulase was stable and retained the activity at optimized conditions. All the cellulaseproducing strains isolated and identified in present study have the potential for further use and future works, such as looking at individual enzyme activities to isolate efficient cellulases with unique characteristics.

\section{Conclusion}

This study identifies some good cellulase producing bacteria from waste (molasses) of sugar industry. Among the isolated strains, Paenibacillus $s p$. exhibited the highest potentiality for maximum cellulase production at optimized conditions and the molecular weight of the purified enzyme was found to be $66.9 \mathrm{kDa}$. Based on substrate specificity test, the purified cellulase showed high specificity on CMC which indicated it to be an endo- $\beta-1,4$-glucanase. Bacterial isolates with cellulase activity might be an important part of our future research to build up effective cellulase producing system that can be favored for industrial applications.

\section{Limitation of the Study}

In present study, we could not perform the molecular characterization of the isolated strains because of our limited laboratory facilities. In our future study, we would like to perform 16s rRNA sequencing for confirming the species identification of individual strain and the structure-function relationship of the purified enzyme by determining $\mathrm{N}$ terminal and C-terminal amino acid sequence.

\section{Abbreviations}

CMC: Carboxymethyl cellulose; DNS: 3, 5-dinitrosalicylic acid; LB: Luria-Bertani;

\section{Availability of Data and Materials}

All data is given in the main body of the manuscript. Data and materials are also available from the corresponding author.

\section{Competing Interests}

The authors declare no conflict of interest.

\section{Funding}

This research did not receive any external funding. 


\section{Authors' Contributions}

FI: Conceptualization, data analysis and interpretation, methodology, manuscript writing. NR: conceptualization, supervision, and critical revision of the manuscript. All authors read and approved the final manuscript.

\section{Acknowledgements}

The authors wish to thank the people who helped in the sampling process. This work was supported by a National Science and Technology Fellowship to Farjana Islam and an internal grant from the department.

\section{References}

[1] Romeo, Tony (2008). Bacterial biofilms. Springer, 258-263, Berlin. ISBN 978-3-540-75418-3.

[2] Potprommanee L, Wang XQ, Han YJ, Nyobe D, Peng YP, Huang Q, Liu JY, Liao YL, Chang KL (2017). Characterization of a thermophilic cellulase from Geobacillus sp. HTA426, an efficient cellulase-producer on alkali pretreated of lignocellulosic biomass. PLoS One. 13;12(4):e0175004.

[3] Klemm, Dieter; Heublein, Brigitte; Fink, Hans-Peter; Bohn, Andreas (2005). Cellulose: Fascinating Biopolymer and Sustainable Raw Material. Angew. Chem. Int. Ed. 44: 3358-93.

[4] Bhat MK (2000). Cellulases and related enzymes in biotechnology. Biotechnol Adv. 1: 355-383.

[5] Shanmugapriya K, Saravana PS, Krishnapriya, Manoharan M, Mythili A, Joseph S (2012). Isolation, screening and partial purification of cellulose from cellulose producing bacteria. International Journal of Advanced Biotechnology and Research 3: 509-514.

[6] Liang YL, Zhang Z, Wu M, Wu Y, Feng JX (2014). Isolation, screening, and identification of cellulolytic bacteria from natural reserves in the subtropical region of China and optimization of cellulase production by Paenibacillus terrae ME27-1. Biomed Res Int. 2014:512497. doi: $10.1155 / 2014 / 512497$.

[7] Perez J, Munoz-Dorado J, de la Rubia T, Martinez J (2002). Biodegradation and biological treatments of cellulose, hemicellulose and lignin: an overview. Int. Microbiol. 5: 53-63.

[8] Gaur R, Tiwari S (2015). Isolation, production, purification and characterization of an organic-solvent-thermostable alkalophilic cellulase from Bacillus allismortis RG-07. BMC Biotechnol. 15:19. doi: 10.1186/s12896-015-0129-9.

[9] Abdelnasser SSI, Ahmed IE (2007). Isolation and Identification of New Cellulases Producing Thermophilic Bacteria from an Egyptian Hot Spring and Some Properties of the Crude Enzyme. Australian Journal of Basic and Applied Sciences 1: 473-478.

[10] Chandara SKR, Snishamol C, Prabhu NG (2005). Cellulase Production by Native Bacteria Using Water Hyacinth as Substrate under Solid State Fermentation: Malaysian Journal of Microbiology 1: 25-29.

[11] Islam F, Roy N (2018). Screening, purification and characterization of cellulase from cellulase producing bacteria in molasses. BMC Res Notes. 11(1):445. doi: 10.1186/s13104018-3558-4.

[12] Cherry JR, Fidantsef AL (2003). Directed evolution of industrial enzymes: an update. Curr Opin Biotechnol. 14: 438-443.

[13] Nakamura K, Kappamura K (1982). Isolation and identification of crystalline cellulose hydrolyzing bacterium and its enzymatic properties. J Ferment Technol 60: 343-348.

[14] Doi RH (2008). Cellulase of mesophilic microbes: cellulosome and non- cellulosome producers: Annals of New York Academy of Sciences 1125: 267-279.

[15] Rasul F, Afroz A, Rashid U, Mehmood S, Sughra K, Zeeshan $\mathrm{N}$ (2015). Screening and characterization of cellulase producing bacteria from soil and waste (molasses) of sugar industry. International Journal of Biosciences. http://dx.doi.org/10.12692/ijb/6.3.230-238

[16] Yin LJ, Huang PS, Lin HH (2010). Isolation of cellulase producing Bacteria and Characterization of the Cellulase from the Isolated Bacterium Cellulomonas Sp. YJ5. J Agric Food Chem 58: 9833-7.

[17] Ando T, Chambost JP, Kotoujansky A, Cattano J, Barras F (1984). Mutants of Erwiniachrysanthemi defective in secretion of pectinase and cellulase. J Bacteriol, 160: 1199-1203.

[18] Azhar A. Hussain, Mohamed S. Abdel-Salam, Hoda H. AboGhalia, Wafaa K. Hegazy, Safa S. Hafez (2017). Optimization and molecular identification of novel cellulose degrading bacteria isolated from Egyptian environment. Journal of Genetic Engineering and Biotechnology 15 (1): 77-85.

[19] Apun K, Jong BC, Salleh MA (2000). Screening and isolation of a cellulolytic and amylolytic Bacillussp from pith waste. J Gen Appl Microbes 46: 263-267.

[20] Buchanan RE, Gibbons NE (1974). Bergey's of determinative bacteriology America: United States of America, 529-563.

[21] Miller GL (1959). Use of Dinitrosalisylic acid reagent for determination of reducing sugars. Anal Chem. 31: 426-428.

[22] Lowry OH, Rosebrough NJ, Farr AL, Randall RJ (1951). Protein measurement with the Folinciocalteu's reagent. J. Biol. Chem 193: 265-275.

[23] Haung XP, Monk C (2004). Purification and characterization of a cellulase from a newly isolated thermophilic aerobic bacterium Caldibacillus cellulovorans gen. nov. sp. World journal of Microbiology and Biotechnology 20: 85-92.

[24] Gopinath SM, Shareef I, Ashalatha, Ranjit S (2012). Isolation, Screening and Purification of Cellulase from Cellulase Producing Klebsiellavaricola RBER3 (KF036184.1). International Journal of Science and Research, 2319-7064.

[25] Irfan M, Safdar A, Syed Q, Nadeem M (2012). Isolation and screening of cellulolytic bacteria from soil and optimization of cellulase production and activity. Turkish Journal of Biochemistry- Turk J Biochem. 37: 287-293

[26] Chundakkadu, K. (1998). Production of bacterial cellulases by solid state fermentation of banana wastes. Bioresou Techniol 69: 231-239.

[27] Nandimath AP, Kharat KR, Gupta SG, Kharat AS (2016). Optimization of cellulase production for Bacillus $\mathrm{sp}$. and Pseudomonas sp. soil isolates. African Journal of Microbiology Research 10: 410-419. 
[28] Lynd LR, Weimer PJ, van Zyl WH, Pretorius IS (2002). Microbial cellulose utilization: fundamentals \& biotechnology. Microbiology and Molecular Biology Reviews 66: 506-577.

[29] Verma V, Verma A, Kushwaha A (2012). Isolation \& production of cellulase enzyme from bacteria isolated from agricultural fields in district Hardoi, Uttar Pradesh, India. Pelagia Research Library 3: 171-174.

[30] Maki ML, Broere M, Leung KT, Qin W (2011). Characterization of some efficient cellulase producing bacteria isolated from paper mill sludges and organic fertilizers. Int $\mathbf{J}$ Biochem Mol Biol 2011;2(2):146-154

[31] Coughlan MP, Mayer F (1992). The cellulose-decomposing bacteria and their enzyme systems. In The Prokaryotes vol. 1, eds. Balows, A., Truper, H. G., Dworkin, M., Harder, W. \& Schleifer, K. H. pp. 460-516. New York: Springer-Verlag.
ISBN 0-38797258-7.

[32] Fu X, Liu P, Lin L, Hong Y, Huang X, Meng X, Liu Z (2010). A novel endoglucanase Cel9P) from a marine bacterium Paenibacillus sp. BME-14. Appl Biochem Biotechnol 160:1627-1636.

[33] Wang CM, Shyu CL, Ho SP, Chiou SH (2008). Characterization of a novel thermophilic, cellulose-degrading bacterium Paenibacillus sp. strain B39. Lett Appl. Microbiol. 47(1):46-53.

[34] Lee YJ, Kim BK, Lee BH, Jo KI, Lee NK (2006). Purification and characterization of cellulase produced by Baciilusamyloliquefaciens DL-3 utilizing rice hull. College of Natural Resources and Life Science 840: 604-714. 